\title{
PRZEMÓWIENIE DZIEKANA WYDZIALU TEOLOGICZNEGO SEKCJA W TARNOWIE UPJPII W KRAKOWIE KS. DRA HAB. IRENEUSZA STOLARCZYKA PODCZAS INAUGURACJI ROKU AKADEMICKIEGO 2013/2014
}

Ekscelencjo, Księże Biskupie, Wielki Wicekanclerzu! Ekscelencjo, Księże Biskupie, Wikariuszu Generalny! Księża Infułaci! Przedstawiciele władz samorządowych i lokalnych! Magnificencje, Panowie Rektorzy tarnowskich uczelni oraz Księża Rektorzy seminariów duchownych! Dostojni Goście! Czcigodni nauczyciele akademiccy Wydziału Teologicznego Sekcja w Tarnowie! Drogie Siostry Zakonne! Drodzy Studenci!

1. Trwający Rok Wiary skupia naszą uwagę na znaczeniu wiary w życiu poszczególnych osób i całych społeczeństw. Katechizm Kościoła Katolickiego przypomina, że ,wiara jest odpowiedzią człowieka daną Bogu, który mu się objawia i udziela, przynosząc równocześnie obfite światło człowiekowi poszukującemu ostatecznego sensu swego życia" (nr 26). Wiara więc porządkuje całe ludzkie życie, staje się też nieodzowną inspiracją porządku społecznego. Wiara, którą motywuje Chrystusowe stwierdzenie: „Wszystko, co uczyniliście jednemu z tych braci moich najmniejszych, Mnieście uczynili" (Mt 25,40), obliguje do stawiania zasadnych i mocnych pytań dotyczących nie tylko życia osobistego, ale także trafności konstrukcji społecznych.

Twórcza refleksja nad znaczeniem wiary w życiu człowieka wyraziła się w licznych dokumentach Kościoła. I tak, papież Leon XIII w encyklice Rerum novarum inicjuje działalność Caritas, która z czasem obejmuje coraz większą ilość państw. Na uczelniach katolickich rozwija się katolicka myśl społeczna, a spośród wiernych wyłania się grupa pionierów demokracji chrześcijańskiej. W wielu krajach organizowane są tygodnie społeczne. Dokument wywarł wpływ nie tylko na ówczesnych, ale zapoczątkował też tradycję pisania encyklik społecznych przez większość następców Leona XIII. Kolejny papież, Pius XI, proponuje w encyklice Quadragesimo anno kilka zasad odnowy ustroju społeczno-gospodarczego: po pierwsze zasadę pomocniczości, po drugie solidaryzm społeczny, po trzecie korporacjonizm chrześcijański. To właśnie w tej encyklice pojawia się również refleksja na 
temat znaczenia miłości w odnowie ustroju społecznego - teza, do której powróci po latach Benedykt XVI w encyklice Caritas in veritatem - papież zatroskania o integralny rozwój ludzki.

Bogactwo inspiracji związanych z dojrzałym przeżywaniem wiary konkretyzują kolejne encykliki społeczne, z których wspomnę tylko kilka: $P a$ cem in terris $\mathrm{z}$ jej koronnym stwierdzeniem, że fundamentem i ukoronowaniem wszystkich działań umacniających pokój na świecie jest ostatecznie umacnianie i kształtowanie pokoju i ładu Bożego w sercu człowieka; Populorum progressio i jej tezę, iż rozwój, ażeby był ludzki, musi być integralny, tzn. ma podnosić całego człowieka, obejmując wszystkie istotne wymiary jego egzystencji, a więc nie tylko wymiar ekonomiczny, ale także społeczny, kulturowy i duchowy. Wspomnijmy jeszcze przesłanie encykliki Laborem exercens, w której Jan Paweł II przypomina, że człowiek jest podmiotem pracy i on jest też jej celem, nigdy zaś narzędziem produkcji; a także niezapomnianą tezę encykliki Centesimus annus, autorstwa tego samego papieża, który proroczo przestrzegał, że demokracja bez wartości łatwo przeradza się w jawny lub zakamuflowany totalitaryzm.

W kontekście tej krótkiej refleksji nad dojrzałą wiarą, która obliguje do stawiania zasadnych i mocnych pytań dotyczących nie tylko życia osobistego, ale także trafności konstrukcji społecznych, wspomnijmy jeszcze encyklikę Caritas in veritate - ogłoszoną przez Benedykta XVI - encyklikę, w której Ojciec Święty trafia w sedno problemów dzisiejszego świata. Papież wykazuje, że ludzkość, zafascynowana możliwościami niemal nieograniczonego rozwoju, zagubiła pewne fundamentalne wartości. W tym sensie takie zmiany, które nie służą rozwojowi człowieka, trudno nazwać postępem. Nie likwidują one bowiem istniejących nierówności, a co gorsza doprowadzają do eskalacji problemów w globalnej skali. Elementarny błąd współczesnej ekonomii polega na tym, że przestano ją pojmować jako jedną z nauk społecznych, mających na celu tworzenie dobra wspólnego. Zaczęto uważać za „autonomiczną wobec wartości” maszynkę do pomnażania zysku. Zapomniano o uniwersalnych cnotach, jak uczciwość, oszczędność czy odpowiedzialność. W efekcie podejmowane są działania nakierowane na szybki zysk, a zgubne w dłuższej perspektywie. Benedykt XVI przypomina, że najważniejszym kryterium postępu gospodarczego jest dobro człowieka i jego integralny rozwój. Zapomnienie o tej fundamentalnej tezie rodzi „błąd antropologiczny", który negatywnie odbija się na wszystkich. Dlatego właśnie papieska diagnoza traktuje integralny rozwój człowieka jako wartość nadrzędną wszelkiego postępu, a globalizację postrzega jako szansę, zauważając przy tym liczne jej deformacje i konieczność otwarcia tego procesu na wartości. Benedykt XVI apeluje o odnowę ekonomii oraz postuluje, by wąsko rozumianą „logikę rynku” zastąpić logiką daru i globalnej solidarności.

2. Przeżywamy Rok Wiary, a wraz z nim rodzącą się refleksję nad znaczeniem wiary, która winna być na tyle silna, by stać się zaczynem przemiany człowieka i całych społeczeństw. Refleksja ta, owocnie podjęta przez 
Kościół i zawarta w stosownych dokumentach, jest także przedmiotem badań naukowych, prowadzonych na Wydziałach Teologicznych. I to właśnie stanowi codzienność istnienia naszego Wydziału, który w dniu dzisiejszym rozpoczyna sto dziewięćdziesiąty drugi rok swojej działalności.

Funkcjonowanie każdej uczelni to wytrwała, ofiarna i mozolna praca wielu konkretnych osób. Instytucja tej miary potrzebuje ich zaangażowania i oddania; jej bogactwo - jak mozaika - składa się właśnie z takich postaw, by ostatecznie ukazać całe swoje piękno. Ekscelencjo, Księże Biskupie Andrzeju, Wielki Wicekanclerzu, przyjmij nasze wspólne podziękowanie za szereg inicjatyw dynamizujących rozwój naszej uczelni - w jej duchowym i materialnym wymiarze. Cenne są wszelkie mobilizujące do dalszego rozwoju podpowiedzi i sugestie, stała ojcowska troska i rodzące się z niej wymagania.

Proszę pozwolić, że na wstępie tej części sprawozdania wyrażę także wdzięczność wobec wszystkich nauczycieli akademickich, których praca naukowa zaowocowała faktem, że 30 września 2013 roku Wydział Teologiczny Sekcja w Tarnowie otrzymał kategorię „A” przyznaną przez Komitet Ewaluacji Jednostek (KEJN) jako wynik ewaluacji jednostek za lata 2009-2012. Gratuluję i życzę wytrwałości w dalszym zaangażowaniu naukowym.

O dynamizmie naszego Wydziału decydują także stopnie i tytuły naukowe uzyskane lub wszczęte przez naszych pracowników naukowych. Ks. dr hab. Marek Kluz uzyskał stopień naukowy doktora habilitowanego nauk teologicznych w zakresie teologii moralnej (według nowych procedur), a ks. dr hab. Robert Biel - w zakresie teologii pastoralnej (według dotychczasowych procedur). Księże Marku i Księże Robercie - cieszymy się i życzymy tego działania, które ubogaci nasz Wydział Waszym profesjonalizmem i zaangażowaniem. Ponadto trzech pracowników WTST wszczęło (według dotychczasowych procedur) postępowania o nadanie tytułu naukowego profesora nauk teologicznych, a dwóch pracowników WTST wszczęło przewody o uzyskanie stopnia naukowego doktora habilitowanego (jeden według dotychczasowych procedur i jeden według nowych procedur).

Radością całego Wydziału jest także fakt, że ks. prof. dr hab. Józef Stala został włączony do grona ekspertów Polskiej Komisji Akredytacyjnej IV kadencji - w ramach zespołu nauk humanistycznych i teologicznych - w zakresie nauk teologicznych i nauk o rodzinie. Księże Józefie - wyrażamy uznanie i życzymy, by to zaszczytne zadanie służyło teologii w Polsce.

Miniony rok akademicki zaowocował również nadaniem kolejnych stopni doktora nauk teologicznych na naszym Wydziale. Uzyskali je - ks. dr Grzegorz Adamski i ks. dr Jan Bartoszek. Drodzy Księża, niech doktorat nauk teologicznych skutecznie służy w budowaniu wiary wśród wiernych powierzonych Waszej trosce apostolskiej.

Wykaz ważniejszych osiągnięć i przedsięwzięć dotyczących Wydziału Teologicznego Sekcja w Tarnowie, jakie miały miejsce w roku akademickim 2012/2013 można zamknąć w poniższych liczbach: 
- prace monograficzne w liczbie 15 - w tym obcojęzyczne;

- artykuły, rozdziały i hasła w liczbie 65 - w tym obcojęzyczne;

- kilkanaście serii wydawniczych, w których ukazują się nasze publikacje;

- 2 złożone projekty naukowe;

- 4 zorganizowane konferencje międzynarodowe;

- 3 zorganizowane konferencje o charakterze ogólnopolskim;

- nauczyciele akademiccy należą do 20 towarzystw i organizacji naukowych oraz współpracują z 29 ośrodkami kształcenia w Polsce i za granicą;

- Wydział Teologiczny Sekcja w Tarnowie ma podpisane umowy o wymianie „Erasmus” z czterema uniwersytetami, redaguje dwa punktowane periodyki i prowadzi własną stronę internetową.

3. Na koniec pragnę skierować słowa podziękowania do wszystkich nauczycieli akademickich, którzy swoją codzienną pracą naukową przyczyniali się do pomyślnych wyników minionego roku akademickiego. Na ręce Księdza Rektora Wyższego Seminarium Duchownego składam wyrazy naszej wdzięczności za każde zaangażowanie się wspólnoty seminaryjnej w przygotowanie tego, co zapewnia możliwość zachowania właściwego rytmu pracy Wydziału - przeprowadzanych wykładów oraz organizowanych konferencji i sympozjów.

Dziękuję również za każdą życzliwość dla naszego Wydziału ze strony władz administracji państwowej i lokalnych władz samorządowych oraz uczelni tarnowskich, zwłaszcza Państwowej Wyższej Szkoły Zawodowej. Dobro wspólne tarnowskiego środowiska to owoc zgodnej współpracy wszystkich ludzi dobrej woli.

Rok akademicki 2013/2014, a sto dziewięćdziesiąty drugi w dziejach naszej Uczelni, ogłaszam za otwarty.

Quod bonum, felix, faustum, fortunatumque sit! 